\title{
Dual Position of Regional Head and Political Party Chairman: Perspective on Digital Society Social Change in State Law
}

\author{
Seto Sanjoyo ${ }^{1}$, Adi Sulistiyono ${ }^{2}$, Agus Riwanto ${ }^{3}$ \\ ${ }_{1,2,3}$ Universitas Sebelas Maret \\ Surakarta, Indonesia \\ setosanjoyo16@student.uns.ac.id
}

\begin{abstract}
The regional head becomes the chairman of a political party, which creates resistance in the monopoly of power. Political parties or a combination of political parties are a means to propose pairs of regional heads and deputy regional heads in the nomination. This study aims to determine the extent of the dual influence of positions in the head and chair of political parties. This research is carried out from the phenomenon of Grobogan Regent's performance. The Regent leads the region from the beginning of his office until the end of his term. This research uses descriptive qualitative method with the method of collecting observational data, interviews, and exploring secondary data both from legislation and literature. The research result was that Grobogan Regent, in his concurrent position as party leader, did not mix party interests with government interests. The Grobogan Regent gave facilitation to fill the empty seat of Grobogan Regent by submitting the filling mechanism to the supporting parties.
\end{abstract}

Keywords-Political Party, Regional Government, Regional Head.

\section{INTRODUCTION}

The separation of power was initiated by Mostesquieu, a French philosopher of law. [1] According to him, the power of the Government must be separated into three, namely: legislative, executive and judicial power in which the three governmental powers differ from each other and do not interfere with each other, but in reality, there is still a relationship of control between the government institutions.[2] The type of government power in the world is divided into three: republic, monarchy, and despotic.[3] Republic means there is a body or some people who exercise the highest authority, where the people have the highest authority in the Government.[4] Monarchy is a government in which one person rules through a fixed and established law, where the king or emperor usually leads the monarchy. An absolute king can also lead a despotic government that is a person who rules all his desires.

Regions in Indonesia, starting from the Provinces, Regencies, and Cities, are given the authority to regulate their regions, called autonomous regions.[5] Regional autonomy is part of decentralization.[6] Regional autonomy comes from Greek, which consists of two words, autos, which has its meaning and nomos, which has the meaning of the law so that autonomy has its legal meaning (zelfwetgeving). Autonomy is the order of ways to divide the tasks and authority and the responsibility to regulate and manage the Government between the central and regional governments. Each region will have a variety of governmental affairs based on surrender, recognition from the central Government, and affairs that are indeed regional domestic affairs.

For each administration, the three types of power must be separate from each other, regarding the task (functie) and the equipment (organ) related to it. According to this thought, there is no justification for interference or influence between one another. Furthermore, in the end, it will be deplorable if the same person or the same institution exercises the three powers, namely establishing the law, carrying out public decisions, and adjudicating the crimes or disputes of individuals. The separation of powers aims to separate power between institutions or bodies that have the authority to make regulations (legislative), institutions or governing bodies (executives), and judicial and law enforcement agencies (judicative).[7] The existence of power separation within the State is regulated in the fundamental law of a country, the Constitutional Law. The constitution is a state document that contains the principal matters of state administration.

Law is a social regulatory tool to enforce regulations and see the extent to which valid law is carried out in society. As Roscoe Pound analyzes the law by fabricating the community as a manifestation of the social law, "Law as a tool of social engineering." The law examines social control, legal socialization, stratification, legal change, and social change by looking at aspects of the legal structure, and law enforcement officers.[8] The strength of the political colour in a coalition in local Government, with one political party controlling half the legislative power, weakens one of the powers of supervision or control by the DPRD institution.[9] During the Grobogan Regency government, political power was very dominant. The regional head is supported by the winning party, which has almost half members, and the winning coalition party is more than half. With the dominance of one of the major parties supporting the regional head, it will comfortably 
oversee all regional head policies. Policies made by the regional head will be quickly approved without political friction. The impact of political stability will also impact the lack of criticism of the Government's running. The regional head as party leader has the more effortless factor in regulating the rhythm of the relationship between the executive and the legislative.

\section{RESEARCH METHOD}

This study used an empirical research method by describing the occurring problems. The researchers interviewed the primary respondent with scientific narration from theories that becoming comparisons in conducted observation. The data was collected qualitatively with direct observation of the primary respondent as an information source. The respondent is selected based on the results of policies made by the holders of power, both executive and legislative.

\section{FINDINGS AND DISCUSSION}

The leader is the person given the power to lead. In the era of Roman glory, power was the relationship between man and his God. The power they have is in the form of theocratic authority, where the command of God gives the authority of a leader or king. Power in governing the king is absolute. Thus Beschikking of the king is the highest rule.[10] The dogmatism of power makes the king the law itself. In the view of philosophers Hegel to Aristotle, 11 countries are the centre of society analogous to a vast subject. Likewise, Plato assumed the concept of the rule of law as macro antrophos (giant humans). The point is the king's position as head, the law as his nervous system, the army as his hand, and the other.

\section{The Resistance of Regional Head as Chair of Political Parties}

Election of Regional Head and Deputy Regional Head is a routine activity carried out by the government through the Regional General Election Commission (KPUD) as the Administrator of the Regional Head General Election (Pemilukada).[11] Since the Indonesian era before independence during the Dutch colonial rule, the regional head elections ranging from the Governor, Regident, Regident assistant, and Regent, were elected directly by the Governor-General of the Dutch East Indies.

Grobogan Regency is led by the regional head of the winning electoral party. She led Grobogan regency from the first general election by herself from the beginning until the end of her term of office. Sri Sumarni, as the Regent, was legitimately elected with her partner, Edy Maryono, a police officer from PKB. Before the inauguration, Edy Maryono died precisely on March $11^{\text {th }}, 2016$. The agenda for the inauguration of the elected Regent and Deputy Regent of Grobogan Regency (2016-2021) period is on March $21^{\text {th }}, 2016$, precisely ten days after the elected Deputy Regent Edy Maryono passed away.
According to Article 65, paragraph 1, Law 23 of 2014, the Regional Head (Regent) has a duty between them in the letter $\mathrm{d}$. The regional head (Regent) proposes the Regional Budget (APBD) draft bylaws (raperda), APBD Amendment draft bylaws, and APBD accountability draft bylaws. The Regent has the task of proposing APBD draft bylaws, which is then discussed together with the DPRD for consultations with the Governor and determined to be the APBD. Political nuance is felt when the joint agreement between the Regent and the Regional Legislative Councils (DPRD), there will be political transactions in the form of budgets and program activities. Political power plays a vital role in discussing the APBD because, in the APBD structure, there are members of the DPRD main thoughts, better known as their constituents' aspirational funds.

Since leading the Grobogan District in 2014, Sri Sumarni has not had a deputy regent, so her daily work as a regional head is done by herself. Due to the complexity and the need for immediate handling, Sri Sumarni opened the open bidding for the post of Regional Secretary at the beginning. Based on the results of the selection by the team won by Moh. Soemarsono, who previously served as the head of the Revenue and Asset Management Agency (BPPKAD). Sri Sumarni's decision to appoint Moh Soemarsono was very well responded by the DPRD and the regional apparatus, besides having work experience, he also had excellent competence by receiving Doctoral education.

As a single regional head supported by a political party winning the election and controlling the legislature, she applied a different concept of regional leadership. The Regent as the executor carries out policy considerations in regulating the regions with the Regional Secretary, which in general, these tasks and authorities are carried out by the deputy regent.[12] The development priority programs outlined in the Regent's vision and mission are fully distributed to the regional apparatus, the Regional Secretary, as the coordinator of the priority program implementation. The Regent wants the concept of development problems to be completed at the regional apparatus level led by the regional secretary. Giving freedom to innovate in achieving the vision and mission is very easy for the head of the regional apparatus to pour the concept. Regional secretary as supervisor and whistleblower if there is a priority program that deviates from the vision and mission.

Sri Sumarni, aside from being the Regent, also served as the head of the winning party, giving additional strength as a "decision maker." The placement of elect persons in the party structure also affected the structure of the DPRD's fittings. The position of chairperson of the DPRD is given to the party secretary, the position of chair of the faction, chair of the banggar, chair of the commission is also politically compromised. The placement of essential posts in guarding regional policies is highly considered. The new face of Grobogan's DPRD membership is almost $60 \%$ 
(sixty per cent), giving optimism to the legislative work culture reform.

\section{The Legitimacy of the Regent without the Deputy Regent}

The regional head is a leader who has the legitimacy to lead in an area, is sworn in, and given the authority and responsibility to manage, develop, and prosper his region, an inseparable part of a country. The authority of the regional head is almost the same as the head of the Government or the President. The difference is the area of coverage and the authority of defence and foreign diplomatic relations. Autonomous power in realizing the region under the characteristics of the area, and having a vision and mission in achieving development during the five years of his leadership made the regional head a symbol of political power in the area. Regional heads are directly elected by people who already have the right to vote after 17 years of age or are married. The community gives confidence through direct elections of regional heads who are considered appropriate, so the strength of both influence and trust of the elected regional head is calculated.[13]

In Europe Countries, UK has a mayor as the head of the region; besides, in America, a mayor and the Governor stand as the head of the State have no deputy in his position. The urgency of the existence of deputy regional heads, in the countries of the world, is more divided into the task of the regional apparatus or regional secretariat as an assistant regional head. The deputy head of the region for developing countries such as Indonesia who are just learning to political democracy, this position is only as a division of political power in the party bearers. The deputy head of the region does not have strategic authority in deciding which policies to use. Financial budget discussion, for example, General Budget Policies and Provisional Budget Ceiling and Priorities (KUA-PPAS) are discussed at the regional apparatus level coordinated by the Regional Secretary, then submitted to the Regional Head to be submitted to the DPRD for joint discussion, the strategic authority of the budget is not the role of the deputy head area.

The first period is almost complete following the mandate of the people will end in March 2021. In the first period of nearly five years of his leadership, the pressure from the public to fill the deputy regent's position was also extreme, but much support for the deputy regent's position was empty for the sake of stability in leading the region. In Indonesia, history was created by Grobogan Regency, the position of Regent Deputy has never been filled from the beginning, and the term of office was less than 18 months, then the constitutional vacancy of the regent deputy's office did not need to be filled. This phenomenon has also occurred in the filling of the Deputy Governor of Central Sulawesi. The position of Deputy Governor was not filled for almost three years of office because of the conflicting interests of each supporting party.
The absence of rules regarding the regulation to fill the position of deputy regional head is required to be filled, and there is no regulation on the obligation of central government intervention to make decisions related to the vacancy of the deputy regional head. The Minister of Home Affairs respects the political process in Grobogan Regency, assuming this is a democratic process between supporting parties. Entirely given authority to the supporting parties to propose a candidate for the deputy regent replacement, if it is taken to remain empty, it is considered a democratic agreement as long as there is no violation of the law and disrupts the running of the Government.

This problem occurs because the legal clarity about the replacement of the deputy head of the region is not sufficient. Law number 10 of 2016 as concerning the second amendment Act number 1 of 2015 concerning Establishment of Government Regulations In lieu of Law number 1 of 2014, it does not provide clarity if the deputy governor and vice-regent die or are unable to remain, by not providing certainty how much time should be filled with coalition parties to fill the vacancy of the deputy head of the region. Changes are needed in the constitution is related to the mechanism of filling the vacancy of the deputy head of the region who died. It means that the phenomena such as in Grobogan Regency did not re-occur and become an example of other regions.

Sri Sumarni in leading the Grobogan Regency during her tenure was not an option from the very beginning. Having a partner and sharing the work with his representatives is the initial goal when running for a candidate in pairs with Edy Maryono. The position and authority of Sri Sumarni in serving as Regent without any representative does not violate any regulation. The policy made also has legal force because it has gone through an approval process with the DPRD. The process of policy legitimacy has been carried out by complying with existing regulations. The process of filling the deputy regent position of Sri Sumarni gave it entirely to the political party supporting the couple.

Performance is tangible proof of service. It is providing the best services, creating work programs that target the basic needs of the community, increasing the workforce numbers as an effort to reduce poverty by making effective the existence of Vocational Training Centers (BLK), improving health facilities, and using performance-based budgets that are effective and targeted. The supporting effort is followed by the quality of the regional apparatus underneath, by dividing all matters downward. The Regional Secretary shares the function of performance control of the apparatus underneath, and the supervisory function is given a role in the Inspectorate.

Support from DPRD members makes it easy for the district government to realize the plans and policies made. A harmonious relationship, although it does not leave the controlling function of the DPRD on the performance of the Regent and the regional apparatus and his staff is 
beneficial and facilitates the implementation of the planned development. Effectiveness is a measure of the level of indicators both the work carried out, the extent to which people or organizations produce the results as desired.[14] It can be concluded that when planning is effective if what is planned with the results of planning has the same and excellent results. APBD budget planning is useful if there is a plan prepared by the Government, discussed and agreed with members of the DPRD and the results of the implementation of the APBD under the planned outcomes.[15]

\section{CONCLUSION}

First, the Grobogan Regent was a central figure in running the wheels of Government. Decision-makers and policymakers who function as masters in the direction of regional development. Regent is a political position obtained through an election nominated by a political party, a combination of political parties and individual candidates submitted through non-political party channels. Sri Sumarni is a Regent who is carried by a combination of several political parties. From the analysis and discussion above, it can be concluded that Sri Sumarni was the first Grobogan Regent (2016-2021) who was a politician from the PDIP (Chairperson of the DPD PDIP). The influence is enormous when the Regent as a political figure and is the leader of the party that wins the election and has the most seats in the DPRD. The experience as chair of the DPRD and members of the DPRD as well as the political abilities to be the leader of a political party is very helpful in solving problems that arise in the RAPBD discussion process.

Second, Regents were elected in pairs with the Deputy Regent in the election. Before the inauguration of the deputy regent candidate, Edy Maryono died. Sri Sumarni as the Regent of Grobogan and the head of a political party had tried to facilitate the supporting party to nominate representatives but never reached an agreement. So Sri Sumarni led the wheels of the Grobogan Regency government to the end of the term of office. Law 23 of 2014 stated that there were no violations of the constitution committed by Sri Sumarni so that all of her policies were legitimate. Political friction in filling the vice-regent candidate does not interfere with the performance in running the Grobogan Regency government. He won various awards from the provincial level to the national level, as well as getting the WTP title from BPK for three years in a row.

\section{REFERENCES}

[1] Zainal Muttaqin E, Konsep Pemisahan Kekuasaan (Separation of Power) Pasca Amandemen UUD 1945 Antara Lembaga Eksekutif dan Legislatif, al Qisthâs; Jurnal Hukum dan Politik, June 2016

[2] Amran Suadi, Sosiologi Hukum Penegakan, realitas dan Nilai Moralitas Hukum, Jakarta, Kencana, 2018

[3] Montesqueie, The Spirit Of Laws Dasar-dasar Ilmu Hukum dan Ilmu Politik, Bandung, Nusa Media, 1977

[4] Nurmiyati. N, Zuhriyati. E, Noor. M, Desentralisasi Politik Dalam Ranah Otonomi Daerah, Jurnal Moderat. Vol. 6. No. 2. Mei 2020
[5] Ni'Matul Huda, Hukum Pemerintahan Daerah, Bandung, Nusa Media, 2017

[6] Ni"emah, Zulfatun, Sosiologi Hukum, Teras, Yogyakarta, 2012

[7] Mahfud, Moh, Politik Hukum di Indonesia, Depok, Rajagrafindo Persada, 2015

[8] Soetandyo Wignjosoebroto, Optik Sosiologi Hukum dalam Mempelajari Hukum, in Paradigma, Wignjosoebroto, Soetandyo, Metode dan Dinamika Masalahnya, Jakarta, 2002

[9] Agus Riwanto, The Construction of Law Neutrality of State Civil Apparatus in the Simultaneous Local Election in Indonesia, Jurnal Yuridika, Vol. 34 No 2, DOI:10.20473/ydk.v34i2.7926, 2019

[10] Jurgen Habermas, Between Facts and Norms,: Contributions to a Discourse Theory of Law and Democracy in Shandi Patria Airlangga, Hakikat Penguasa dalam Negara Hukum Demokratis, Cepalo, 3(1), 2019

[11] Bungasan Hutapea, Dinamika Hukum Pemilihan Kepala Daerah di Indonesia Tahun, Jurnal Rechstvinding, Pusat Penelitian dan Pengembangan Sistem Hukum Nasional, September 2015

[12] Rudi Hermanto, Faktor-Faktor Yang Menyebabkan Munculnya Calon Perseorangan Pada Pemilihan Bupati dan Wakil Bupati Garut, FISIP UIN Ar-Raniry Banda Aceh, Internasional Journal of Government ans Social Science, June 2013

[13] Saldi Isra and Khairul Fahmi, Pemilihan Umum Demokratis PrinsipPrinsip Dalam Konstitusi Indonesia, Depok, Rajawali Pers, 2019.

[14] I. B Dharmanegara, Penganggaran Perusahaan. Yogyakarta: Graha Ilmu, 2010

[15] Siregar, Baldric, Akuntansi Sektor Publik. Edisi kedua, Yogyakarta, UPP STIM YKPN, 2017. 